\title{
Falling on their feet: young workers, employment, and age discrimination
}

\author{
Alysia Blackham
}

Youth (un)employment continues to cause UK policy-makers major headaches. The unemployment rate for $16-24$ year olds was $16.2 \%$ in the quarter from October to December 2014, compared with $5.7 \%$ for the general working population. ${ }^{1}$ Further, $27 \%$ of unemployed 16-24 years olds had been unemployed for over 12 months. ${ }^{2}$ The Resolution Foundation estimates that $37 \%$ of those employed on zero hours contracts are aged between 16 and $24,{ }^{3}$ indicating that young people are often consigned to insecure, precarious jobs when they find work.

In this context, age discrimination legislation has significant potential to address institutional barriers facing younger workers. By prohibiting direct and indirect discrimination in employment on the basis of age, the Employment Equality (Age) Regulations 2006, SI 2006/1031, and now the Equality Act 2010, offer young workers at least the possibility of tackling discriminatory conduct and practices. However, the case of Lockwood v Department of Work and Pensions ${ }^{4}$ provides a telling critique of how well young people might be able to challenge age discrimination in employment and assert their employment rights.

\section{FACTS AND CASE HISTORY}

Ms Lockwood was employed by the Department of Work and Pensions (DWP) as an administrative officer from the age of 18 for eight years. In 2007, Ms Lockwood's position was 'declared surplus' and she applied for release under a voluntary redundancy scheme. Under the scheme, Ms Lockwood was entitled to compensation in accordance with the Civil Service Compensation Scheme (CSCS). The CSCS provided for compensation for voluntary redundancy of:

(a) one month's pay for each year of service, plus

(b) the lesser of:

(i) one month's pay for each year of service given after 5 years service and

(ii) one month's pay for each year of service given after the employee's $30^{\text {th }}$ birthday, plus

(c) one month's pay for each year of service after the employee's $35^{\text {th }}$ birthday,

subject to a maximum compensation cap of three years' pay.

Ms Lockwood, then aged 26, was entitled to $£ 10,849.04$ in compensation under the scheme. Had Ms Lockwood been aged 35 at the time, her total payment would have been $£ 28,539.62$. Thus, Ms Lockwood received around $38 \%$ of the payment that a 35 year old would have received.

\footnotetext{
${ }^{1}$ James Mirza-Davies, 'Youth Unemployment Statistics' (Commons Library Standard Note, 26 February 2015) 1; ONS, 'Employment up 103,000 Compared with the Previous Quarter' (ONS, 18 February 2015) <http://ons.gov.uk/ons/rel/lms/labour-market-statistics/february-2015/sty-labourmarket-statistics--february-2015.html> accessed 3 March 2015.

${ }^{2}$ Mirza-Davies (n 1) 1.

${ }^{3}$ Matthew Pennycook and others, 'A Matter of Time: The Rise of Zero-Hours Contracts' (June 2013) 10.

${ }^{4}$ [2013] EWCA Civ 1195, [2014] ICR 1257 ('Lockwood').
} 
Ms Lockwood challenged the disparity in payments under the Employment Equality (Age) Regulations 2006, SI 2006/1031 reg 3 (now Equality Act 2010 s 13) as a form of direct discrimination. The parties agreed that Ms Lockwood's treatment constituted direct age discrimination. The two issues to be determined were:

1. Whether Ms Lockwood was in materially comparable circumstances to employees aged 35 or above whose employment was terminated, in accordance with reg $3(2) ;^{5}$ and

2. If so, whether the disparity of payment was justified (that is, whether it was a proportionate means of achieving a legitimate aim under reg 3(1)).

The Employment Tribunal (ET) held that there were material differences between those aged below 30 and those above the age of 35 . Those below 30 were likely to have 'lesser financial and family obligations', and therefore 'could generally be expected to react more easily and rapidly to the loss of their jobs and greater flexibility could be expected of them. ${ }^{6}$ Thus, the groups were in materially different circumstances, and there was no age discrimination given the requirement in reg 3(2).

In the event there was age discrimination, the ET held that this was justified as a proportionate means of achieving a legitimate aim. The aim of the CSCS was to 'produce a proportionate financial cushion until alternative employment was found, or as a bridge to retirement and the receipt of a pension'. The means of achieving this aim, via staged payments and a banding process, was proportionate due to six considerations:

- administrative workability required clear bands, and could not allow for the consideration of individual circumstances;

- leveling-up (to pay all employees the same as older workers) would be a 'substantial burden on the public purse';

- statistics showed that younger employees had fewer family and financial obligations and suffered unemployment for a shorter period;

- workforce recruitment and planning supported the scheme;

- 'cogent business aims' and proportionality outweighed the discriminatory effect of the scheme; ${ }^{8}$ and

- the unions had not sought to challenge the scheme or argue it was discriminatory.

The Employment Appeal Tribunal (EAT) upheld the ET's decision that there were material differences between those aged below 30 and those above the age of 35 . Further, if there was discrimination, the ET was entitled to conclude that the measures were a proportionate means of achieving a legitimate aim.

\section{DECISION IN THE COURT OF APPEAL}

In the Court of Appeal, Ms Lockwood argued that:

\footnotetext{
${ }^{5}$ Which requires that: 'A comparison of B's case with that of another person ... must be such that the relevant circumstances in the one case are the same, or not materially different, in the other.'

${ }^{6}$ Lockwood (n 4) 1264 (Rimer LJ).

${ }^{7}$ Ibid.

${ }^{8}$ It is unclear how this is a separate consideration, given this was essentially the issue to be determined by the ET.
} 
1. The ET had misapplied reg 3(2), and was wrong in concluding that there was no less favourable treatment; and

2. The ET had applied an incorrect test of material justification under reg 3(1), ignored material considerations and took irrelevant considerations into account.

\title{
A. The comparator
}

Rimer LJ, delivering the leading judgment in the Court of Appeal, dealt decisively with the comparator issue, labeling the ET's approach 'wrong'. ${ }^{9}$ There was 'no difficulty in identifying a comparator', namely someone aged over 35 who was, or would have been, in all material respects in the same position as Ms Lockwood in their employment at the DWP. ${ }^{10}$ Ms Lockwood's age could not be used to make her circumstances materially different to the comparator. ${ }^{11}$

Using a comparator of someone aged over 35, 'there was only one answer to the question whether she had suffered such less favourable treatment, namely yes. ${ }^{, 12}$ Ms Lockwood would be paid substantially less money upon leaving her employment than someone aged over 35. When the ET 'rejected this straightforward conclusion', it adopted an approach that was 'self-evidently wrong'. ${ }^{13}$ According to the Court of Appeal, there was 'no question that Ms Lockwood suffered less favourable treatment than her comparator'. ${ }^{14}$ Lewison LJ put this conclusion rather pointedly:

\begin{abstract}
When she left her job Ms Lockwood received less money than a 36 year old would have received. Why? The answer is: because she was younger. The ET said that the statistics showed that someone like Ms Lockwood would be able to react more easily and rapidly to losing her job than a 36 year old. Why? The answer again is: because she was younger. They also said that someone like Ms Lockwood would be less likely to have heavy financial responsibilities than a 36 year old. Why? The answer yet again is: because she was younger. Accordingly all the suggested reasons for concluding that Ms Lockwood did not suffer age discrimination turn out to be factors consequent upon her age. They are, therefore, not legitimate differences for the purpose of deciding whether discrimination has taken place. ${ }^{15}$
\end{abstract}

The comparator issue raised by this case is, on the face of it, fairly straightforward: courts and tribunals should not use characteristics relevant to age to determine whether a comparator is in materially different circumstances to the claimant. Characteristics associated with particular age groups may be relevant to justification (see further below), but should not constitute material differences for identifying a comparator. ${ }^{16}$

What is concerning is how long this issue took to resolve, and that the EAT endorsed the ET's approach. This perhaps reflects broader issues with the use of a comparator to establish discrimination, and enduring confusion regarding

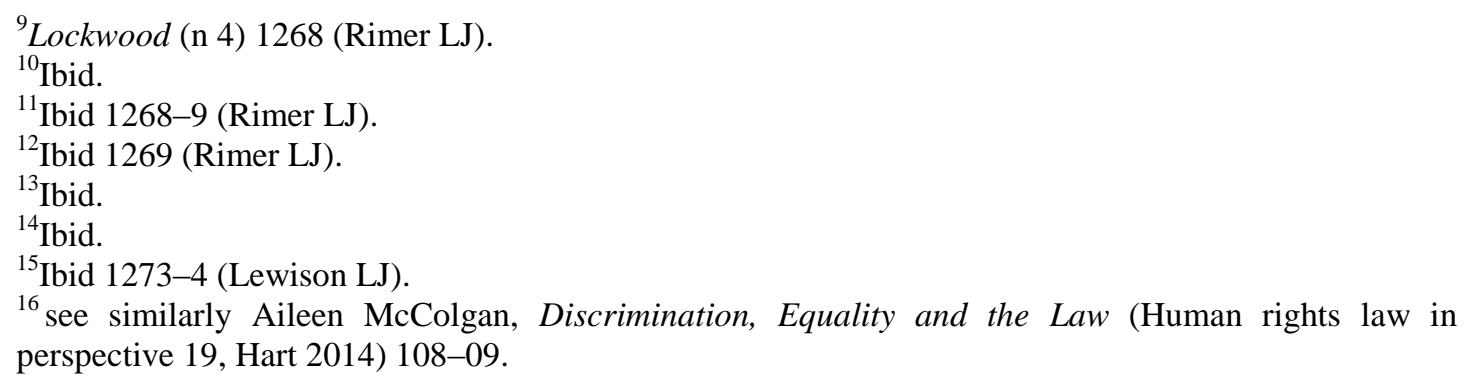


whatattributes should be assigned to a comparator. ${ }^{17}$ The risks and 'dangers' of identifying a comparator and focusing on material differences associated with a protected characteristic were acknowledged in AL (Serbia) v Secretary of State for the Home Department by Baroness Hale: 'it is wrong to focus on the personal characteristics which are inherent in their protected status to argue that their situations are not analogous. 18

Similarly, in Shamoon v Chief Constable of the Royal Ulster Constabulary, ${ }^{19}$ Lord Nicholls cast doubt on the usefulness of the comparator requirement as a determining factor in discrimination claims. These doubts were reinforced by Lord Hope's judgment in that same case:

[T] he need for a comparator has been one of the most problematic and limiting aspects of direct discrimination as defined in the legislation about discrimination on grounds of sex and race.... the choice of comparator requires that a judgment must be made as to which of the differences between any two individuals are relevant and which are irrelevant. The choice of characteristics may itself be determinative of the outcome... . This suggests that care must be taken not to approach this issue in a way that will defeat the purpose of the legislation, which is to eliminate discrimination $\ldots .^{20}$

Drawing on Lord Nicholls approach in Shamoon v Chief Constable of the Royal Ulster Constabulary, ${ }^{21}$ Collins et al. argue that once less favourable treatment has been established by reason of a protected characteristic, the use of a comparator should be largely a formality. ${ }^{22}$ However, Lockwood shows that the use of a comparator continues to generate confusion, even where less favourable treatment is clear. ${ }^{23}$ Thus, there is a need to reconsider the role of the comparator in discrimination cases, particularly where less favourable treatment is clearly evident.

\section{B. Proportionality}

While Ms Lockwood was successful in relation to the first issue, her claim floundered in relation to justification. In reviewing the ET's treatment of the proportionality issue, Rimer LJ held:

[T] here is no substance in the challenge to the ET's reasoning upholding the respondents' objective justification case. The ET's reasons were manifestly full and conscientious. There is no doubt that the ET understood the applicable test; it gave the most careful consideration to the evidence; and it applied the test with obvious care and, in my view, appropriate rigour. ${ }^{24}$

\footnotetext{
${ }^{17}$ see further ibid ch 4.

${ }^{18}$ [2008] UKHL 42, [2008] 1 WLR 1434, 1445 (Baroness Hale of Richmond).

${ }^{19}$ [2003] ICR 337, 342.

${ }^{20}$ Ibid $350-1$.

${ }^{21}$ Ibid 342.

${ }^{22}$ Hugh Collins and others, Labour Law (Law in context, Cambridge University Press 2012) 327.

${ }^{23}$ for further critique of the 'comparator' approach, see Sarah Hannett, 'Equality at the Intersections: The Legislative and Judicial Failure to Tackle Multiple Discrimination' (2003) 23 Oxford J Legal Studies 65.

${ }^{24}$ Lockwood (n 4) 1271-2 (Rimer LJ).
} 
Thus, Ms Lockwood's claim could not succeed, as the discrimination was held to be a proportionate means of achieving a legitimate aim.

\section{RECONSIDERING PROPORTIONALITY}

In the ET, Ms Lockwood was self-represented, and failed to produce any evidence to counter the DWP's factual submissions on proportionality. As noted by Rimer LJ:

The ET in this case, as in most cases, was deciding an adversarial contest between opposing parties. It was no part of its function to step into the arena and assume an inquisitorial role in its inquiry as to the question of proportionality raised by regulation 3 . It had to deal with that issue on the basis of the evidence before it. ...all [Ms Lockwood] is asking for is a remission of the case to the ET for a re-consideration of the proportionality exercise. Any such re-consideration would be on the same evidence. ${ }^{25}$

This raises serious issues about the conduct of proceedings in the ET, particularly given changes to legal aid funding ${ }^{26}$ and the rise in self-represented litigants. ${ }^{27}$ Thus, the evidential issues raised by Lockwood may have broader significance for thinking about how we address discrimination claims.

While Ms Lockwood did not present evidence challenging the DWP's submissions on proportionality, it is informative to consider whether they might have been rebutted using contrary evidence (and, thus, whether Ms Lockwood's challenge on this second issue could have been upheld had different evidence been presented at first instance).

\section{A. Administrative workability}

The ET held that administrative workability of the CSCS required clear age bands, and could not allow for the consideration of individual circumstances. The Court of Appeal summarised the evidence of the DWP as follows:

There are some 600,000 employees across the Civil Service and related bodies who are potentially covered by the CSCS. It is important to ensure that the eligibility criteria and level of benefit applicable to particular individuals are easily understood and administratively workable. There must be what were referred to as 'bright lines'; i.e. rules that can be operated across the Civil Service in order to achieve consistency and operational effectiveness. It is not possible to look at each individual case to determine benefits for each

\footnotetext{
${ }^{25}$ Ibid $1272-3$.

${ }^{26}$ See Legal Aid, Sentencing and Punishment of Offenders Act 2012 (UK) c 10, Schedule 1, Part 1, s 43. While discrimination claims can still obtain legal aid funding, many claims are initially raised as employment matters, meaning the reforms are likely to have an indirect 'chilling' effect on individual age discrimination claims: see EHRC, 'Response of the Equality and Human Rights Commission to the Consultation on Reform of Legal Aid in England and Wales' (15 November 2010) 11.

${ }^{27}$ see further Richard Moorhead and Mark Sefton, 'Litigants in Person: Unrepresented Litigants in First Instance Proceedings' (DCA Research Series, March 2005); Kim Williams, 'Litigants in Person: A Literature Review’ (Research summary, June 2011).
} 
individual; the rules must allocate benefits by reference to clear rules that can be applied with certainty in every case. ${ }^{28}$

The aim of payments under the scheme was to provide 'financial protection that reflects [individuals'] presumed personal circumstances', without actually considering what those circumstances were. ${ }^{29}$ How an individual would react to the loss of their job, or their personal financial position, would be 'very difficult if not impossible to calculate'. ${ }^{30}$

However, issues with assessing individual circumstances do not necessarily mean that age bands are required. Indeed, the CSCS rules were changed in 2010, after Ms Lockwood's departure from the DWP, to remove 'age banding' for younger employees. Voluntary redundancy payments under the CSCS now consist of one month's pay for every year of service, up to a maximum of: 21 months for those under scheme pension age; and 6 months for those over scheme pension age. This appears to undermine the need for age banding for those aged under 35 under the old scheme.

Further, determining 'presumed personal circumstances' on the basis of age is highly likely to lead to injustice and inefficiency, and looks 'suspiciously like stereotyping'. ${ }^{31}$ In this case, the ET found that Ms Lockwood's personal circumstances were 'more akin' to those aged over $35 .{ }^{32}$ It would be revealing to consider how many other young employees at the DWP were in a similar situation. This clearly illustrates how damaging age stereotypes can be, and the 'mismatch between reality and past assumptions or stereotypes'.

In this case, both parties accepted the need for an 'age banding' approach to determine the payment of redundancy money, and to allocate limited resources among employees who were assessed by the employer to have different needs at different ages. ${ }^{34}$ Thus, it was accepted that some disparate treatment of employees of different ages was necessary. ${ }^{35}$ It is possible that this concession was wrongly made, as it certainly undermined Ms Lockwood's arguments relating to justification.

\section{B. Costs argument}

Second, the ET held that the disparate treatment was justified on the basis that leveling-up (to pay all employees the same as older workers) would be a 'substantial burden on the public purse'. ${ }^{36}$ The costs of leveling-up must be seen in the broader context of public service redundancies: the ET heard evidence that there were around

\footnotetext{
${ }^{28}$ Lockwood (n 4) 1262.

${ }^{29}$ Ibid.

${ }^{30}$ Ibid 1263. This echoes the 'one size fits all approach' in retirement cases: see Lucy Vickers and Simonetta Manfredi, 'Age Equality and Retirement: Squaring the Circle' (2013) 42 Ind Law J 61.

${ }^{31}$ Seldon v Clarkson Wright and Jakes [2012] UKSC 16 [57] (Lady Hale) ('Seldon').

${ }^{32}$ Lockwood (n 4) 1263, 1272.

${ }^{33}$ Submissions by Age UK, cited in Seldon (n 31) [15] (Lady Hale).

${ }^{34}$ Lockwood (n 4) 1272.

${ }^{35}$ Ibid.

${ }^{36}$ Ibid 1263, 1264 (Rimer LJ). Ms Lockwood advanced her case on the basis that her payment should be levelled up, reducing the court's focus on any argument that the scheme could be levelled down at no cost to the public purse: see $1270,1273$.
} 
34,000 departures on CSCS terms from 2005 to $2008,{ }^{37}$ at an overall cost of $£ 337$ million. ${ }^{38}$ This is obviously a huge cost to the public purse, and represents a dubious form of workforce management (see further below).

Recent cases considering the relevance of cost considerations in justifying age discrimination have endorsed a 'costs plus' approach: costs alone are not sufficient. ${ }^{39}$ However, it may be possible to define a legitimate aim sufficiently broadly to make costs an inherent part of the legitimate aim (e.g. to carry out a legitimate redundancy exercise without additional cost to the employer). ${ }^{40}$ Given the ET's acceptance of the administrative workability argument in this case, having recourse to cost considerations was entirely acceptable as part of a 'costs plus' approach. Thus, this aspect of the judgment is in full accordance with existing case law.

\section{Statistics regarding the superior position of young people}

Third, the disparate treatment was justified using statistics that showed that younger employees had fewer family and financial obligations (and therefore should be expected to be more 'flexible'), and suffered unemployment for a shorter period. ${ }^{41}$ According to the ET, this was evidenced by:

- 'the higher turnover of employees in the different age categories': turnover of Civil Service employees up to the age of 24 was $8.8 \%$; as compared with $3.9 \%$ for employees aged 35 to 39 ; and

- ONS statistics relating to young people moving into employment from unemployment: ${ }^{42}$ an unemployed $18-24$ year old was $11.2 \%$ more likely to move into employment than someone aged 35-49; and a 25-34 year old was $8.1 \%$ more likely. ${ }^{43}$

The ET also found that young people had fewer financial commitments compared with their older colleagues. This was based on the average age of marriage (in 2007, 34 for women and 36 for men); and the average age of first time house buyers (from 2002-2007: 32 or 33; and by 2009: around 37).

There are a number of issues with these conclusions. First, at a basic level, the ET was unclear regarding which age groups were being compared at what stage. In effect, the CSCS created three categories of redundant workers: those under 30 (including Ms Lockwood); those aged between 30 and 35; and those 35 or over. To be proportionate, there should have been some justification for each of these divisions (and, more particularly, for the division affecting Ms Lockwood). However, the

\footnotetext{
${ }^{37}$ Ibid 1262.

${ }^{38}$ Ibid 1263.

${ }^{39}$ see Woodcock v Cumbria Primary Care Trust [2012] IRLR 491.

${ }^{40}$ Ibid.

${ }^{41}$ Lockwood (n 4) 1262.

${ }^{42}$ Ibid 1272, 1262.

${ }^{43}$ Ibid 1262. This may be compared with Galt v National Starch \& Chemical Limited ET/2101804/07, where the ET was not prepared to accept, without any evidence, the assertion that older workers found it more difficult to find new work; and MacCulloch v Imperial Chemical Industries plc [2008] IRLR 846, where Elias J held that the ET was entitled to draw on its own experiences to conclude that older workers found it harder than younger workers to find alternative employment, and that the ET did not need to hear evidence on this.

${ }^{44}$ Lockwood (n 4) 1263,1272.
} 
statistics that were presented tended to focus on those under 25 and those over 35 , rather than considering the three different groups affected by the scheme. ${ }^{45}$

Second, the statistics relied on by the DWP, and accepted by the ET, present only a partial and distorted picture of youth employment in the UK. For example, even at the time of Ms Lockwood's redundancy, youth unemployment was already increasing, and had been doing so since $2005 .{ }^{46}$ This is depicted in Table 1. Indeed, unemployment for young people was substantially higher than older adult unemployment from 1992 to $2014 .^{47}$ This may reflect young people's limited skills and experience, which mean they 'are less likely to be employed than older adults even during relatively benign periods in the labour market. ${ }^{48}$

\begin{tabular}{lrrrrrrrrr}
\hline Year & \multicolumn{1}{c}{$\mathbf{2 0 0 5}$} & \multicolumn{1}{c}{$\mathbf{2 0 0 6}$} & \multicolumn{1}{c}{$\mathbf{2 0 0 7}$} & $\mathbf{2 0 0 8}$ & $\mathbf{2 0 0 9}$ & $\mathbf{2 0 1 0}$ & $\mathbf{2 0 1 1}$ & $\mathbf{2 0 1 2}$ & \multicolumn{1}{c}{$\mathbf{2 0 1 3}$} \\
\hline All ages & 4.8 & 5.4 & 5.3 & 5.6 & 7.5 & 7.8 & 8.1 & 7.9 & 7.6 \\
$<\mathbf{2 5}$ & 12.8 & 13.9 & 14.3 & 15.0 & 19.1 & 19.8 & 21.3 & 21.2 & 20.7 \\
$\mathbf{2 5}$ to $\mathbf{7 4}$ & 3.3 & 3.8 & 3.6 & 3.9 & 5.6 & 5.8 & 5.8 & 5.7 & 5.4 \\
\hline
\end{tabular}

Table 1: UK unemployment rate by age groups (annual average, \%), 2005-13 (Source: Eurostat Labour Force Survey)

Further, movements into employment from unemployment are likely to be influenced by many factors other than age. ${ }^{49}$ Even if young people are more likely to move into employment from unemployment than older workers (and this has been questioned by some studies), ${ }^{50}$ this may well be linked to the lack of employment protection for younger workers. ${ }^{51}$ Thus, these statistics may become circular, as a lack of employment protection (and resulting job mobility) justifies a further downgrading of protection for young workers.

There is also no guarantee that younger workers entering employment from unemployment will find a 'decent' job. Young people are disproportionately represented in precarious work. ${ }^{52}$ While precarious work may arguably be a

\footnotetext{
${ }^{45}$ This may reflect issues with the available statistics, which rarely distinguish different age bands to this extent.

${ }^{46}$ Tom McInnes and others, Monitoring Poverty and Social Exclusion 2014 (Joseph Rowntree Foundation 2014) 74.

${ }^{47}$ ibid.

${ }^{48}$ ibid.

${ }^{49}$ see Steven Pinch and Colin Mason, 'Redundancy in an Expanding Labour Market: A Case-Study of Displaced Workers from Two Manufacturing Plants in Southampton' (1991) 28 Urban Stud 735; David Bailey and others, 'Employment Outcomes and Plant Closure in a Post-Industrial City: An Analysis of the Labour Market Status of MG Rover Workers Three Years On' (2012) 49 Urban Stud 1595.

${ }^{50}$ Mike Donnelly and Dora Scholarios, 'Workers' Experiences of Redundancy: Evidence from Scottish Defence-dependent Companies’ (1998) 27 Personnel Review 325, 335.

${ }^{51}$ see, for example, Lawrence M Kahn, 'The Impact of Employment Protection Mandates on Demographic Temporary Employment Patterns: International Microeconomic Evidence’ (2007) 117 The Economic Journal F333.

${ }^{52}$ Robert MacDonald, 'Precarious Work: Risk, Choice and Poverty Traps' in Andy Furlong (ed), Handbook of Youth and Young Adulthood: New Perspectives and Agendas (Routledge 2009) 16869.See further Surhan Cam and others, 'Contingent Employment in the UK' in Ola Bergström and Donald W Storrie (eds), Contingent Employment in Europe and the United States (Edward Elgar Publishing 2003) 70; Andy Furlong and Fred Cartmel, 'Vulnerable Young Men in Fragile Labour Markets: Employment, Unemployment and the Search for Long-Term Security’ (2004) 27-33.
} 
temporary and natural dynamic of labour force transitions for younger workers,${ }^{53}$ it may equally be a trap, particularly for those at the bottom end of the labour market (e.g. in the cleaning and catering industries). ${ }^{54}$ For the less privileged or advantaged, precarious work may come to define their experience of employment. ${ }^{55}$ Even relatively prosperous young people have seen their wages, earnings and incomes badly affected by the crisis. ${ }^{56}$ According to Hills et al, the ill effects of the crisis 'have been concentrated on one particular generation', namely those born in the 1980s. ${ }^{57}$ This may lead to 'scarred' employment careers for an entire generation. ${ }^{58}$ Further, the crisis has impacted unevenly across different geographical localities. ${ }^{59}$ Sweeping generalisations regarding the employability of younger workers are clearly inappropriate in this context.

Third, due to their family and financial responsibilities, the ET felt that older workers had 'greater need', ${ }^{60}$ and therefore warranted higher redundancy payments. In the Court of Appeal, counsel for Ms Lockwood argued that the CSCS and ET had not sufficiently considered the "family and financial responsibilities of co-habitees in their twenties', like Ms Lockwood. ${ }^{61}$ Further, the ET had failed to scrutinise the statistical evidence laid before it by the DWP: 'evidence of how young people in their twenties would react to unemployment was no more than an assumption; [the DWP] drew inferences from the statistics that were not justified; and [these] inferences involved a stereotyping of young people that was also not justified. ${ }^{62}$ However, the Court of Appeal held that, on the evidence before them, the ET 'was entitled to be satisfied on the evidence that the position of cohabitees in their twenties was reflected in the statistics before them and that they did not represent some special class whose presence operated to skew the statistics. ${ }^{, 63}$

In this case, Ms Lockwood had not 'provided evidence to show that such cohabitees have onerous financial commitments, such as mortgages and children, to the same degree as those who are married'. ${ }^{64}$ Had Ms Lockwood looked for evidence to rebut the DWP's arguments, it would have been readily available. ONS figures for 2013 show that only $53 \%$ of live babies born that year were born to parents who were married or in a civil partnership. At the same time, $84 \%$ of babies were born to parents in a stable long-term relationship - that is, those married, in a civil partnership or cohabitating. Thus, unsurprisingly, cohabiting couples often have children together.

\footnotetext{
${ }^{53}$ MacDonald (n 52) 169.

${ }^{54}$ ibid 170.

${ }^{55}$ ibid. See also Steve Fenton and Esther Dermott, 'Fragmented Careers? Winners and Losers in Young Adult Labour Markets' (2006) 20 Work Employment Society 205.

${ }^{56}$ John Hills and others, 'Winners and Losers in the Crisis: The Changing Anatomy of Economic Inequality in the UK 2007-2010' (July 2013) 44-50.

${ }^{57}$ ibid 8.

${ }^{58}$ MacDonald (n 52) 173; Hills and others (n 56) 8.

${ }^{59}$ see Ron Martin, 'The Local Geographies of the Financial Crisis: From the Housing Bubble to Economic Recession and beyond' [2010] J Econ Geogr 1.

${ }^{60}$ Lockwood (n 4) 1263.

${ }^{61}$ Ibid 1272.

${ }^{62}$ Ibid 1271.

${ }^{63}$ Ibid 1272.

${ }^{64}$ Ibid.
} 
Cohabitees are also likely to own property together, with law firm Slater \& Gordon describing mortgage as 'the new marriage'. ${ }^{65}$

The focus on cohabitees in the Court of Appeal may have been more distracting than helpful in determining whether the CSCS was proportionate. The real question for the ET should have been whether financial commitments reliably varied by age and, if so, whether this was relevant for determining if the scheme was proportionate. Just because young people do not have a mortgage or children does not mean that they lack onerous financial commitments or have less 'need' for redundancy payments. Individuals struggle to pay rent just as much as they struggle to keep up with mortgage repayments, ${ }^{66}$ and mortgages may have more scope for flexibility and adjustment than rental payments. Not having a mortgage in no way provides an accurate representation of an individual's financial commitments, particularly as younger buyers are increasingly excluded from the housing market. ${ }^{67}$ It seems contrary to logic and unfair to use young people's difficulties in entering the housing market as a justification of age discrimination in employment: those with mortgages are the 'lucky ones' in the modern housing market. ${ }^{68}$ Similarly, individuals may put off marriage and parenthood due to job insecurity and difficulties finding appropriate housing, ${ }^{69}$ which is likely to be reinforced and exacerbated by age discrimination in employment. Young workers are also disproportionately employed in low-wage jobs, as demonstrated in Table 2, meaning they are less likely to have savings to 'tide them through' until they find new employment.

\begin{tabular}{lrr}
\hline Year & 2006 & \multicolumn{2}{c}{ 2010 } \\
\hline All ages & 21.77 & 22.05 \\
$<\mathbf{3 0}$ & 49.97 & 40.61 \\
$\mathbf{3 0 - 4 9}$ & 14.36 & 14.68 \\
$\mathbf{5 0 +}$ & 18.49 & 18.31 \\
\hline
\end{tabular}

Table 2: UK Low-wage earners as a proportion of all employees (excluding apprentices) by age (Source: Eurostat Structure of Earnings Survey)

Thus, the ET's equation of marriage and property ownership with financial commitment and 'need' rings hollow, as young people increasingly cohabit or live in de facto relationships; are excluded from the property market; and incur other

\footnotetext{
${ }^{65}$ 'Why Cohabitation Agreements Are Invaluable For Cohabiting Couples' (Slater \& Gordon Lawyers, 27 November 2013) <http://www.slatergordon.co.uk/media-centre/press-releases/2013/11/whycohabitation-agreements-are-invaluable-for-cohabiting-couples/> accessed 18 February 2015.

${ }^{66}$ see Shelter England, '1.4 Million Britons Falling behind with the Rent or Mortgage' (Shelter, 4 January

<http://england.shelter.org.uk/news/january_2013/1.4_million_britons_falling_behind_with_the_rent_ or_mortgage $>$ accessed 18 February 2015.

${ }^{67}$ Robbie de Santos, 'A Better Deal: Towards More Stable Private Renting' (September 2012) 5; Joseph Rowntree Foundation, 'First-Time Buyers by Age over Time' (Joseph Rowntree Foundation, 8 May 2014) <http://data.jrf.org.uk/data/first-time-buyers/> accessed 18 February 2015.

${ }^{68}$ Shelter Media England, 'Shelter Launches Call for Changes to Private Renting' (Shelter, 21 September)

<http://media.shelter.org.uk/home/press_releases/shelter_launches_call_for_changes_to_private_rentin g> accessed 18 February 2015.

${ }^{69}$ John Bingham, 'Average Age of Women Giving Birth Now Nearly 30', The Telegraph (London, 15 October 2013) <http://www.telegraph.co.uk/women/mother-tongue/10380260/Average-age-of-womengiving-birth-now-nearly-30.html $>$ accessed 18 February 2015.
} 
financial responsibilities. Indeed, financial management may actually be easier if individuals are married or cohabitating in joint-income partnerships, as costs can be shared. Further, expecting young workers to be more 'flexible', and presumably to move to find new employment, is unrealistic when $26 \%$ of $20-34$ year olds are now living in the family home, largely as a result of growing unemployment and workplace insecurity. ${ }^{70}$ In sum, then, the ET's use of statistical evidence risks devolving into a vicious cycle: age discrimination can be justified against younger workers, as they have fewer personal and financial obligations; and young people incur fewer personal and financial obligations as they have less employment security.

While the ET's use of statistics may be criticised, even more concerning is where the Court of Appeal did not require evidence to support the ET's assertions. Counsel for Ms Lockwood challenged the ET's statement that 'someone who starts work in the Civil Service aged 20 is less likely to view the job as a long term career, as against someone who starts at the age of $35^{\prime} .{ }^{71}$ According the Court of Appeal, this was either justified by the DWP's turnover statistics (which do not speak to the employees' intentions or valuing of their work) or else 'was within the specialist knowledge of the lay members of the ET'. Again, this looks suspiciously like age stereotyping, relying on assumptions that younger workers are less committed to their job. $^{72}$

\title{
D. Recruitment and planning
}

Fourth, the ET held that the CSCS was supported by considerations of workforce recruitment and planning. According to the DWP,

\begin{abstract}
In order to attract, engage and retain high calibre staff, the Civil Service had to offer terms that would both be inviting to prospective staff and act as an incentive to existing staff. This included not only a reasonable package of terms during the period of employment, but generous terms after leaving service. This is part of work force planning. Early termination terms must be attractive, so that individuals volunteer for departure when work force numbers need to be reduced. ${ }^{73}$
\end{abstract}

While this may support the scheme generally, it does not explain why the age bands were justified. Further, if there were 34,000 departures on CSCS terms from 2005 to $2008^{74}$ across a potential workforce of 600,000 employees, this represents a significant level of voluntary redundancy payments, creating a turnover of nearly $6 \%$ on that basis alone. ${ }^{75}$ It is arguable that voluntary redundancy payments on this scale

\footnotetext{
${ }^{70}$ ONS, 'Large Increase in 20 to 34-Year-Olds Living with Parents since 1996' (Office for National Statistics, 21 January 2014) <http://www.ons.gov.uk/ons/rel/family-demography/young-adults-livingwith-parents/2013/sty-young-adults.html> accessed 18 February 2015; Juliet Stone and others, 'The Changing Determinants of UK Young Adults' Living Arrangements' (2011) 25 Demographic Research 629.

${ }^{71}$ Lockwood (n 4) 1273.

${ }^{72}$ For a critique, see H Kirk Dansereau, 'Work and the Teen-Ager' (1961) 338 The Annals of the American Academy of Political and Social Science 44; Christina Cregan, 'Young Workers and the JobSwapping Phenomenon' (1991) 5 Work Employment Society 417.

${ }^{73}$ Lockwood (n 4) 1262.

${ }^{74}$ Ibid.

${ }^{75}$ This may reflect broader shifts in public service human resource management practices: see Philip Morgan and Nigel Allington, 'Has the Public Sector Retained Its “Model Employer" Status?' (2002) 22 Public Money \& Management 35.
} 
represent an unreasonable use of public money, and are certainly a blunt and costly tool for 'workforce planning'.

\section{E. Union support}

Finally, the ET noted that the unions had not sought to challenge the scheme or argue it was discriminatory, supporting the proportionality of the differential treatment. This case obviously placed the unions in a difficult position: while older members would likely wish to retain their enhanced redundancy payments, younger members were being put at a distinct disadvantage. This reflects broader issues with unions intervening in equality matters. While unions may play a significant role in promoting good practice on equality issues, ${ }^{76} \mathrm{UK}$ trade unions have generally come to the equality agenda slowly and reluctantly. Further, younger workers are generally underrepresented in union management and are often poorly unionised. ${ }^{77}$ While some unions are working to address this imbalance, ${ }^{78}$ it is unrealistic to assume that the union would object to the CSCS in its entirety, or to make the unions' lack of objection an indicator of proportionality.

\section{CONCLUSION}

The terms of the CSCS scheme challenged in Lockwood are now of only historical significance: since the scheme's amendment in 2010, the provisions that directly discriminated against younger workers have been removed. Thus, this judgment is most relevant to those who took voluntary redundancy prior to 2010, and is unlikely to have much practical significance going forward.

However, the judgment provides significant insights into the likely challenges young claimants will face in proving that age-related provisions are not proportionate. This case strongly affirms the lesser weight afforded to age as a protected characteristic: age discrimination is seen as 'different' to other forms of discrimination, ${ }^{79}$ and is regarded as less harmful or detrimental (and, therefore, less worthy of protection). ${ }^{80}$ It is inconceivable that a similar provision explicitly linking redundancy pay to gender or race would be legally or socially acceptable, or that such a provision would be able to be objectively justified under legislation. By treating age discrimination as 'different' and less harmful than other forms of discrimination, the law continues to condone ageism and perpetuate ageist values, as illustrated by Lockwood.

\footnotetext{
${ }^{76}$ see, for example, Anne-marie Greene and Gill Kirton, 'Trade Union Perspectives on Diversity Management' in Mustafa Özbilgin (ed), Equality, diversity and inclusion at work: a research companion (Edward Elgar 2009) 265-66.

${ }^{77}$ see Stephanie Tailby and Anna Pollert, 'Non-Unionized Young Workers and Organizing the Unorganized' (2011) 32 Economic and Industrial Democracy 499.

78 See, for example, UNISON, 'The Future is Here' (UNISON, 2015) $<$ http://www.unison.org.uk/about/our-organisation/member-groups/young-members/young-membersmonth/the-future-is-here/ $>$ accessed 18 February 2015; TUC, 'Young Workers' (TUC, 2015) <http://www.tuc.org.uk/about-tuc/young-workers> accessed 18 February 2015.

${ }^{79}$ Malcolm Sargeant, 'Mandatory Retirement Age and Age Discrimination' (2004) 26 Employee Relations 151, 154.

${ }^{80}$ ibid; Stephen McNair and Matthew Flynn, 'The Age Dimension of Employment Practices: Employer Case Studies' (Employment Relations Research Series, June 2005) 11.
} 
Lockwood also flags ongoing issues relating to the use of comparators in UK discrimination law. Far from being a 'formality', the selection of a comparator is causing confusion and uncertainty in the ET and EAT, and may be leading to the dismissal of otherwise legitimate claims. While the Court of Appeal's decision has hopefully dispelled some of this confusion, it is timely to review whether we should require a formal comparator, particularly in cases of direct discrimination. In the government's response to the consultation on the Equality Bill, it noted that it had elected to retain the comparator requirement as it 'reflects that discrimination is principally about equal rather than fair treatment. ${ }^{, 81}$ Indeed, the government felt that courts would struggle to assess claims of discrimination without a comparator: 'A comparator remains one of the best ways to measure "different" treatment. " The contrary view, as expressed by the Law Society and Discrimination Law Association in the consultation, was acknowledged by the EAT in Islington London Borough Council v Ladele: ${ }^{83}$

[A]lthough the Directive and the Regulations both identify the need for a tribunal to determine how a comparator was or would have been treated, that conclusion is necessarily encompassed in the finding that the claimant suffered the detriment on the prohibited ground. So a finding of discrimination can be made without the tribunal needing specifically to identify the precise characteristics of the comparator at all.

This is likely the better approach.

The Court of Appeal's approach in Lockwood can also be contrasted with recent CJEU decisions on age-based pay rates. The CJEU appears to treat payments that disadvantage young workers with a healthy degree of skepticism. For example, in Specht $v$ Land Berlin ${ }^{84}$ and Hennigs (Social policy) ${ }^{85}$ it was held that basic pay rates determined by an employee's age at the time of recruitment were not a proportionate means of recognising employee experience. Indeed, the CJEU in Hennigs refused to accept that older age was correlated with more onerous financial responsibilities: 'it has not been shown that there is a direct correlation between the age of employees and their financial needs. Thus a young employee may have substantial family burdens to bear while an older employee may be unmarried without dependant children. ${ }^{86}$ This approach stands in marked contrast to that in Lockwood. ${ }^{87}$

Overall, existing cases indicate that the evidence presented at first instance, particularly regarding whether older workers have more difficulties finding new employment, will largely be determinative of the issue of justification. This places a high burden on self-represented litigants, who will likely need to challenge an employer's statistical evidence at first instance (and, in all likelihood for younger

\footnotetext{
${ }^{81}$ UK Government, The Equality Bill - Government Response to the Consultation (Stationery Office 2008) para 7.10.

82 ibid.

${ }^{83}$ [2009] ICR 387, 395.

${ }^{84}$ [2014] EUECJ C-501/12 (19 June 2014); [2014] ICR 966.

${ }^{85}$ [2011] EUECJ C-297/10 (08 September 2011).

${ }^{86}$ ibid [70].

${ }^{87}$ Compare also Kücükdevici v Swedex GmbH (C-555/07) [2009] EUECJ C-555/07 (09 July 2009) and Hütter v Technische Universitat Graz (C-88/08) [2009] EUECJ C-88/08 (18 June 2009), where it was held that not taking into account experience under a particular age was not proportionate.
} 
workers, without union support). ${ }^{88} \mathrm{~A}$ more inquisitorial system of adjudication for discrimination claims, which was explicitly distinguished in the Court of Appeal judgment from the ET system, could well have a use in this case. In sum, age discrimination laws may service to undermine, rather than support, younger workers' already precarious position in the labour market. We can only hope (albeit unrealistically) that younger workers will somehow fall on their feet without legal assistance.

\footnotetext{
${ }^{88}$ See, for example, MacCulloch $v$ Imperial Chemical Industries plcET 2700083/2007, where the claimant tried to use statistics to rebut the assertion that redundant older workers found it more difficult to find work than younger workers. The ET was not persuaded by the statistics, which merely showed percentages in and out of the job market, and relied on their own experience of the difficulty older workers have in finding work.
} 